\title{
MOTORCYCLE RACING INJURIES ON TRACK AND ROAD CIRCUITS IN IRELAND
}

\author{
C. H. HORNER, MB, BCh, BAO, BA* and A. A. O'BRIEN, MB, MRCPI** \\ * Lecturer in Anatomy, Anatomy Department, Trinity College, Dublin \\ **Lecturer, Department of Cliniçal Medicine, Trinity College, Dublin
}

\begin{abstract}
A retrospective study was carried out on all motorcycle injuries occurring at Mondelo Park racetrack for the 1983 and 1984 seasons. In this sport there were a total of 57 injuries for the two year period, 27 occurring in 1983 and 30 in 1984 . Soft tissue injuries accounted for $66.7 \%$, fractures $22.8 \%$ and head injuries $10.5 \%$ of the total. In the fracture group, 2 patients suffered spinal fractures which is noteworthy in that neither were wearing back protectors which as yet are not compulsory safety equipment in Eire.
\end{abstract}

These figures were compared with data from the same two year period on the Ulster road circuit. The incidence of each type of injury was similar and equally low in both groups. Motorcycle racing injuries compared favourably with motor car racing injuries and had a lower incidence of serious head injury. In comparison with road traffic accidents involving motorcyclists the overall number of injuries, the number of serious head, abdominal and chest injuries and the overall fatality rate, are much lower. The two most relevant factors in our lower injury incidence were lack of alcohol and the absence of collision with cars. Experience, medical attention and speed had no direct influence on our injury incidence.

\section{INTRODUCTION}

Mondelo Park is the national racetrack for Eire and international riders are encouraged to attend some of the yearly meetings. The season, lasting from March to October, consists of approximately 9 race meetings, with between 100 and 120 riders participating, sometimes more than once each day. As the legend on every programme states "Motorcycle Racing is Dangerous", this study was carried out to find the incidence, nature and extent of motorcycle injuries on track circuits.

As a comparison, data collected from motorcycle road circuit meetings in Northern Ireland, motor car racing meetings in England and road traffic accidents involving motorcyclists have been compared with our data.

\section{METHODS}

All motorcycle injuries recorded for the years 1983 and 1984 were grouped according to type of injury. The treatment given and the outcome of the injuries was noted. Many more competitors had falls from motorcycles but did not require medical attention and these are not included in the figures quoted.

All riders had restricted racing permits and the motorcycles were checked for road worthiness prior to competition. The consumption of alcohol is strictly forbidden among competitors. The motorcycle engine ranged from $50 \mathrm{cc}$ to unlimited class.

Soft tissue injuries were strapped and sutured as deemed appropriate. All head injuries had a full neurological examination and were considered unfit to continue racing. All fractures were referred to hospital for $\mathrm{X}$-ray.

\section{RESULTS}

During each season nine motorcycle track meetings were held at Mondelo. Fifteen races took place each day with an average of 15 riders per race, giving a total of 2025 participants per season (approximate). In Northern Ireland

Address for correspondence:

Dr. Catherine H. Horner

Department of Anatomy

Trinity College

Dublin 2

Eire eight road race meetings were held each season consisting of six events with approximately 48 competitors per event. Hence 2304 competitors took part during each season. The injury figures were as follows:

a) Overall Incidence of Injury

$$
\begin{aligned}
& \begin{array}{l}
\text { Motorcycle Track } \\
\text { (Mondelo) }
\end{array} \\
& 1983-27 / 2025=1.3 \% \\
& 1984-30 / 2025=1.5 \%
\end{aligned}
$$

$$
\begin{aligned}
& \text { Motorcycle Road } \\
& \text { (Northern Ireland) } \\
& 1983-46 / 2304=2.0 \% \\
& 1984-43 / 2304=1.9 \%
\end{aligned}
$$

b) Types of Injury

The 57 injuries recorded at Mondelo comprised 38 soft tissue injuries, 13 fractures and 6 head injuries, while the 89 Ulster road circuit injuries comprised 60 soft tissue injuries, 16 fractures, 10 head injuries, one internal injury to the chest and one fatality. The fractures at Mondelo consisted of 10 limb fractures, one rib fracture and two spinal fractures. The spinal fractures occurred at $\mathrm{L} 3$ and $T 10$ with no residual neurological deficit. Four of the six head injuries sustained at Mondelo had loss of consciousness compared with three of 10 head injuries seen on the road circuit.

c) Injury Related to Age

(i) The average age of competitors at Mondelo was 19 years (range 17 to 38 years).

(ii) More than $60 \%$ of competitors were less than 20 years of age.

(iii) The average age of those injured was 20.5 years.

d) Comparison of Motorcycle Track and Road, Motor Car Track and Road and Road Traffic Accidents Involving Motorcycles:

Comparison of the above is shown in Table I. The motorcycle racing fatality number is much lower than that of road traffic accidents. This is partly explained by the almost total absence of serious injuries to head, abdomen and chest which were the commonest cause of road traffic accident deaths. The motorcycle figures compare favourably with the motor car racing figures apart from a higher number of serious head injuries in the latter.

\section{DISCUSSION}

We documented 57 injuries in a two year period of motorcycle track racing. These are much lower figures than 
TABLEI

Comparison of motorcycle, track and road, motor car, track and road and road traffic accident (involving motoreycles) injuries

\begin{tabular}{|c|c|c|c|c|c|c|c|}
\hline & $\begin{array}{c}\text { Motorcycle } \\
\text { Track }\end{array}$ & $\begin{array}{c}\text { Motorcycle } \\
\text { Road }\end{array}$ & $\begin{array}{r}\text { Ros } \\
\text { Moore * }\end{array}$ & $\begin{array}{l}\text { ad Traffic } \\
\text { Andrew }\end{array}$ & $\begin{array}{l}\text { Accidents } \\
\text { Whittington }\end{array}$ & $\begin{array}{c}\text { Motor Car* } \\
\text { Track }\end{array}$ & $\begin{array}{l}\text { Motor Car* } \\
\text { Road }\end{array}$ \\
\hline $\begin{array}{l}\text { Serious Head } \\
\text { Injury }\end{array}$ & 0 & 1 & N.S. & 8 & 31 & 12 & 10 \\
\hline Spinal Fracture & 2 & 0 & 5 & 0 & 0 & 2 & 5 \\
\hline Limb Fracture & 10 & 16 & 51 & 69 & 15 & 11 & 8 \\
\hline $\begin{array}{l}\text { Abdomen/Chest } \\
\text { Injury }\end{array}$ & 0 & 1 & 0 & 19 & 36 & 1 & 5 \\
\hline Fatalities & 0 & 1 & 0 & 4 & 82 & 0 & 0 \\
\hline $\begin{array}{l}\text { Number of people } \\
\text { studied }\end{array}$ & $\begin{array}{c}4050 \\
\text { (approx.) }\end{array}$ & $\begin{array}{c}4600 \\
\text { (approx.) }\end{array}$ & 100 & 145 & 82 & $1000+$ & $300+$ \\
\hline Study Period & $2 y r s$ & 2 yrs & $10 \mathrm{mths}$ & $6 \mathrm{mths}$ & $\begin{array}{c}\text { Fatality } \\
\text { Review } 3 \text { yrs }\end{array}$ & 4 yrs & 6 yrs \\
\hline
\end{tabular}

N.S. $=$ Not Stated

* = Reproduced from de Dombal et al (1979)

the 145 motorcycle road accidents seen by Andrew (1979) in a 6 month period and the 1905 motorcycle road injuries documented in Eire during the same two year period (An Foras Forbartha 1983 and 1984). The motorcycle injury figure compares favourably with those of motor car injuries (de Dombal et al, 1979).

In analysing our low incidence of motorcycle injuries the following factors seem relevant.

1. Alcohol

In 3 of Harrop and Wilson's (1982) 17 deaths, 16 of Whittington's (1982), 56 deaths and 44\% of Moore and Sheehan's (1985) injuries, alcohol consumption was implicated in the aetiology of the accident. None of our injured riders had consumed alcohol on the day of racing.

2. Collision with Cars

In $70 \%$ of Mackay's (1975) series and $30 \%$ of Andrew's (1979) series of motorcycle injuries, collision with cars was the event leading to injury. Obviously this was not a factor in track racing. Collision with trees, walls, and even spectators is a constant danger on road circuit racing and this danger is reflected in the one fatality in this series.

3. Experience

Experience is difficult to analyse scientifically. It is generally held that the more experienced the rider the less the risk of injury. The majority of our injuries occurred in relatively inexperienced riders.

4. Medical Attention

The presence of trained medical personnel is of course mandatory at both track and road motorcycle meetings. Their presence however did not directly influence the incidence of injury. Only three serious injuries were seen in a two year period on both road and track, out of thousands of possible serious injuries, but medical attention did influence the outcome of serious injuries.

5. Speed

Speed has been implicated by Whittington (1982) and by Moore and Sheehan (1985) as contributing to the mortality and morbidity of motorcycle accidents. It is difficult to reconcile speed on its own as a risk factor with our low injury incidence figure in a so-called high speed sport. It is interesting to note that Moore and Sheehan (1985) found a higher speeding incidence in a 30 m.p.h. zone and that Whittington's (1982) mortality figure was highest in the urban $\mathbf{3 0}$ m.p.h. zone.

The majority of our fractures occurred in the limbs. The limbs seem to be the most vulnerable site since they are used to break falls and to protect more important parts such as the head. Our head injury figures were low, this figure tending to rise where fatalities occur (Avery, 1979; Harrop and Wilson, 1982; Mackay, 1975 and Whittington, 1982). Our fatality number is low because of the lack of serious head and internal abdominal and chest injuries. Our low head injury rate is almost certainly due to the protective helmet. Of our 13 fractures, two involved the spine with fortunately no neurological deficit. We feel that in a relatively safe sport such as motorcycle track racing (Table 1) that this figure is unacceptably high. Neither of the riders involved were wearing back protectors as indeed were few of the total number of participants. The incidence of spinal fractures in motorcycle track racing should be further studied in a larger series when the case for compulsory use of a back protector could be better assessed.

\section{ACKNOWLEDGEMENTS}

We acknowledge the help of the Officials of the Motorcycle Union of Ireland and all the Doctors involved in motorcycle racing.

\section{References}

Andrews, T. A., 1979 "A Six Month Review of Motorcycle Accidents". Injury 10: 317-320.

An Foras Forbartha. Road Traffic Accident Figures 1983 and 1984. Government Publications, Dublin 2.

Avery, J. G., 1979 "Motorcycle Accidents in Teenage Males - A Modern Epidemic". The Practitioner 222: 369-380.

de Dombal, T., Perkins, M. and Eve, M., 1979 "Rally Doctors". Medisport 2: 6-8.

Harrop, S. N., Wilson, R. Y., 1982 "Motorcycle Fatalities in South West Cumbria". Injury 13: 382-387.

Mackay, G. M., 1975 “Motorcycle Accidents". J.For.Sc.Soc. 15: 7.

Motorcycle Union of Ireland, Ulster Circuit (M.C.U.I.(U.C.) Ltd.) Personal Communication from Liaison Officer.

Moore, D. P. and Sheehan, J. M., 1985 "Speed, Alcohol and Road Traffic Accidents". J.Ir.Coll.Physician and Surgeons 14(2): 65-67.

Whittington, R. M., 1981 "Motorcycle Fatalities: Analysis of Birmingham Coroner's Records". Injury 12: 267-273. 